\title{
36. MICROSTRUCTURAL STUDY OF THREE PERIDOTITE SAMPLES DRILLED AT THE WESTERN MARGIN OF THE MID-ATLANTIC RIDGE
}

\author{
Francoise Boudier, Laboratoire de Tectonophysique, Université de Nantes, Nantes, France
}

\section{INTRODUCTION}

This study deals with serpentinized peridotite samples drilled in Hole 395 by Glomar Challenger during Leg 45 of the Deep Sea Drilling Project. The site is at $\sim 22^{\circ} \mathrm{N}$ on the west side of the Mid-Atlantic Ridge, on magnetic anomaly $4 \mathrm{a}$ (see Chapter 7 , this volume). The samples belong to two intervals of serpentinized peridotite ( $15 \%$ to $30 \%$ serpentine), each about 1 meter thick, interlayered with aphyric basalt about 160 meters beneath the water/sediment interface, and probably tectonically emplaced. The upper sliver is harzburgite (Samples 395-18-1, 110-128 cm, piece 2g, and $18-1,139-150 \mathrm{~cm}$, piece $2 \mathrm{i}$ ), the lower is spinel lherzolite (Sample 395-18-2, 135-140 cm, piece 17f).

\section{STRUCTURE}

Within the core, and in pieces $2 \mathrm{i}$ and $2 \mathrm{~g}$, a foliation dipping at about $45^{\circ}$ may be defined by the flattening of enstatite augen. In piece $17 \mathrm{f}$, only a cleavage is observed, owing to serpentinization. Olivine is present as porphyroclasts ( 5 to $10 \mathrm{~mm}$ ) with a very weak shape fabric, and as a few per cent of recrystallized neoblasts $(1 \mathrm{~mm})$. The olivine substructure is coarse, with sharp (100) sub-boundaries (Figure 1) and a weak disorientation between subgrains.

Enstatite crystals are flattened porphyroclasts ( 5 to $10 \mathrm{~mm}$ ) (Figure 2), with thin (100) exsolution lamellae. They show undulous extinction and a substructure with sharp (001) sub-boundaries. In the lherzolite sample, spinel is associated with enstatite (Figure 3 ). This is very common in mantle peridotites with a protogranular texture (Mercier and Nicolas, 1975).

In the spinel lherzolite, clinopyroxene is porphyroclastic ( 3 to $8 \mathrm{~mm}$ ), frequently associated with enstatite (Figure 4). It contains (100) exsolution lamellae. The substructure is well developed with (001) sub-boundaries. In a large porphyroclast the clinopyroxene is recrystallized along the sub-boundaries into $0.1-\mathrm{mm}$ neoblasts (Figure 5); this recrystallization occurred after deformation.

In some occurrences, an idiomorphic type of clinopyroxene is observed (Figure 6). Where present in the harzburgite, it shows the (100) twinning (Figure 7) which is observed in magmatic clinopyroxenes.

\section{MINERAL PREFERRED ORIENTATION}

The mineral preferred orientation measured in the harzburgite piece $2 \mathrm{~g}$ (Figure 9 ) is very poor. Olivine shows a weak [010] girdle which would be perpendicular to the assumed foliation plane, and a vague tendency to a [001] maximum in the foliation plane. The enstatite shows no preferred orientation.

\section{DISLOCATIONS IN OLIVINE}

Dislocations in olivine have been observed (Y. Gueguen, personal communication) with the optical microscope by the technique of decoration. The dislocation density is $5.10^{6} / \mathrm{cm}^{2}$, which is the order of magnitude characteristic of basalt xenoliths (Gueguen, 1977). (100) walls are observed (Figure 8), but the recovery is not complete. Many loops are present, but also straight dislocations. The gliding system is $(010)$ [100]. These observations indicate a moderate to high temperature of deformation.

\section{DISCUSSION}

The samples studied present a tectonized fabric. Subgrains in olivine and enstatite with sharp $(100)_{\text {ol }}$ and $(001)_{\mathrm{en}}$ sub-boundaries indicate that these rocks have been deformed in the mantle at high temperature (more than $1000^{\circ} \mathrm{C}$ ). The observed $(010)[100]$ gliding system in olivine deduced from the dislocation study, and the character of the dislocations, suggest also a relatively high temperature of deformation. This is emphasized by the recrystallization of deformed clinopyroxene. The deformation is probably weak, as shown by the poor shape fabric of olivine and poor mineral preferred orientation. This deformation has been superimposed on a pre-existing structure. The large size of the crystals and the mode of association of spinel with orthopyroxene suggest a mantle structure; the harzburgite would be residual after partial melting, but the possibility of an ancient cumulus structure cannot be definitively discarded. The occurrence of two types of clinopyroxenes, especially the one with magmatic twinning, raises an interesting possibility: if the harzburgite were residual after melting, the magmatic clinopyroxene could have crystallized from trapped partial melt.

\section{REFERENCES}

Gueguen, Y., 1977. Dislocations in mantle peridotite nodules, Tectonophysics, v. 39, p. 231-254.

Mercier, J. C. and Nicolas, A., 1975. Textures and fabrics of upper mantle peridotites as illustrated by basalt xenoliths, J. Petrol., v. 16, p. 454-498. 


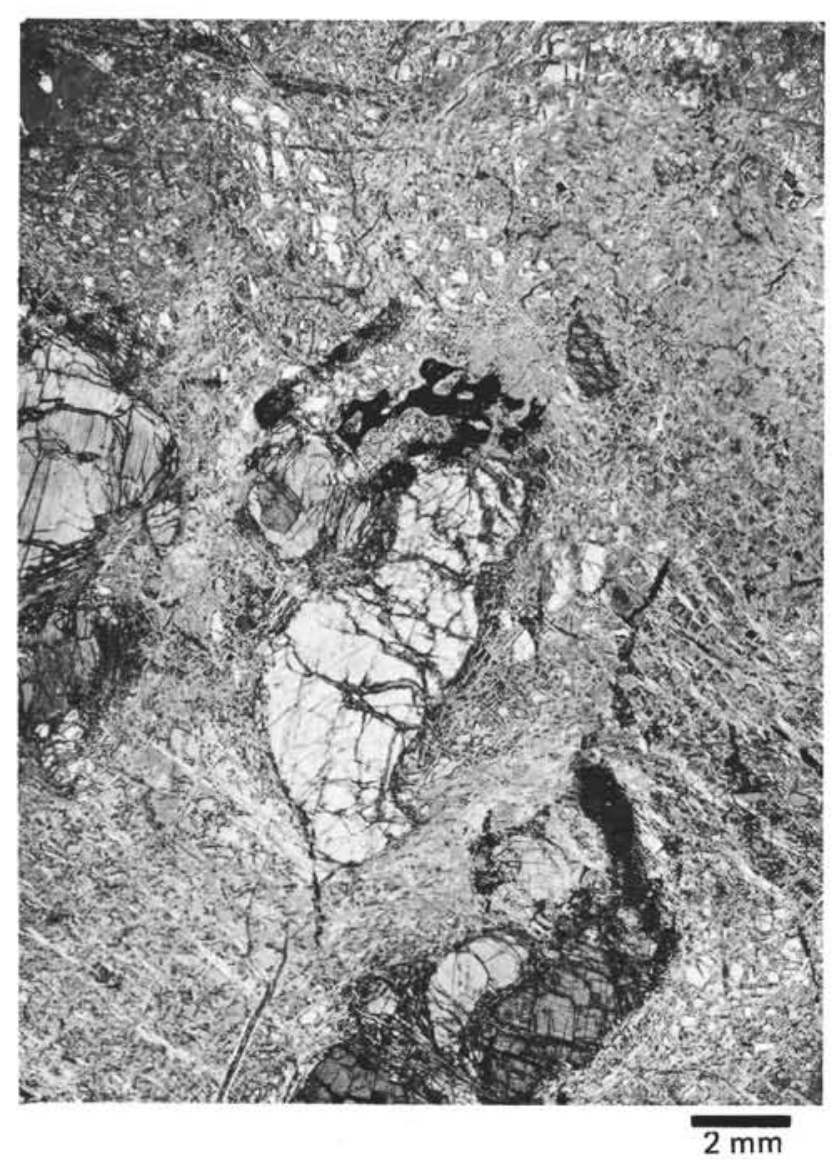

Figure 1. Photomicrograph of an enstatite porphyroclast associated with spinel and with porphyroclastic clinopyroxene (dark gray). Lherzolite, piece $17 f$; crossed nicols.

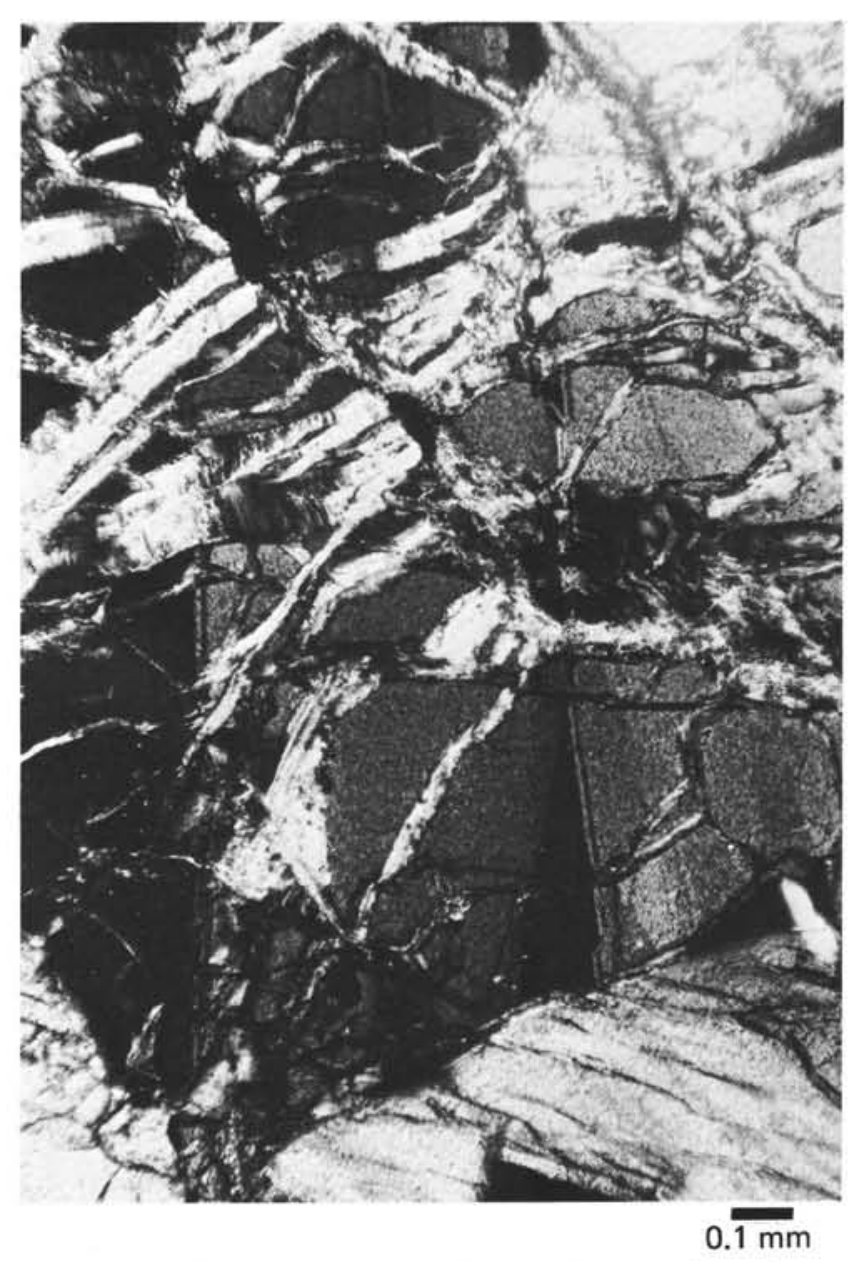

Figure 2. Photomicrograph of an olivine porphyroclast with sharp (100) sub-boundaries. Harzburgite, piece $2 g$; crossed nicols. 


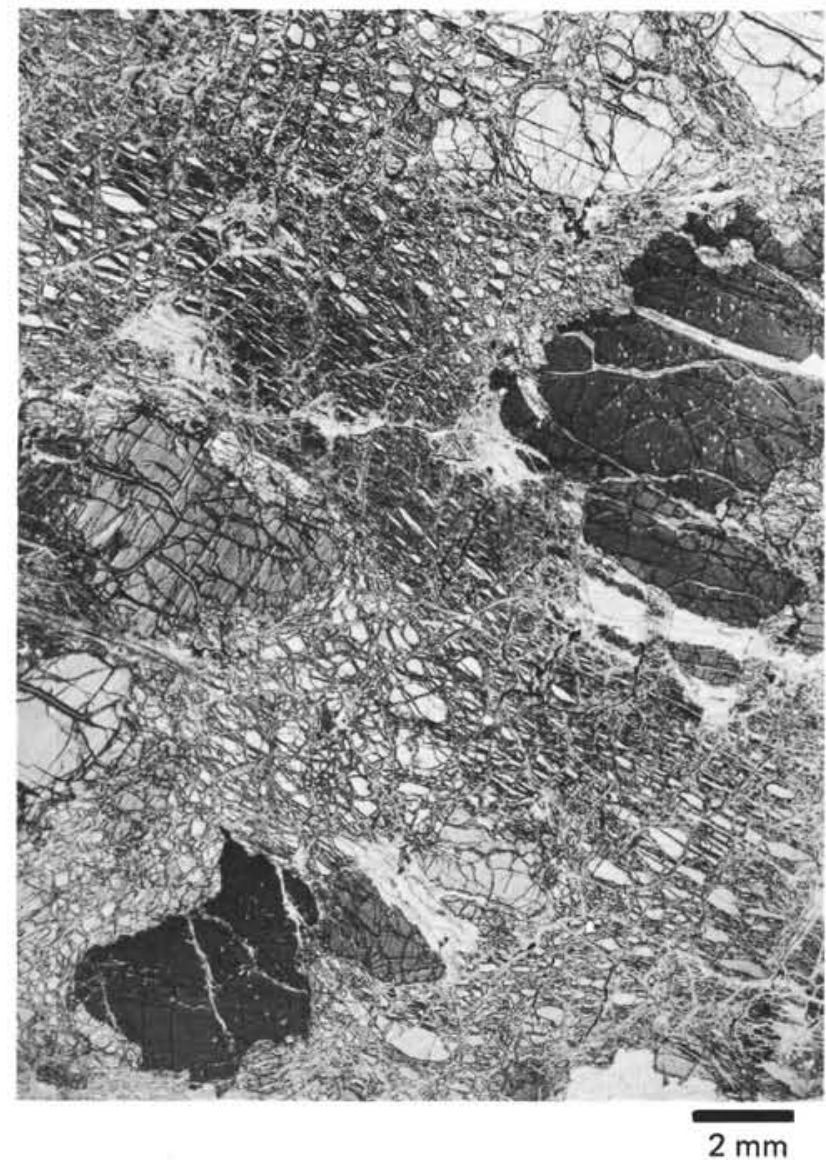

Figure 3. Photomicrograph of harzburgite, piece $2 g$, in a thin section cut perpendicular to the foliation whose trace is southwest-northeast on the figure. Elongated enstatite sections contain (100) exsolution lamellae. The principal plane of serpentinization is perpendicular to the trace of the foliation. Crossed nicols.

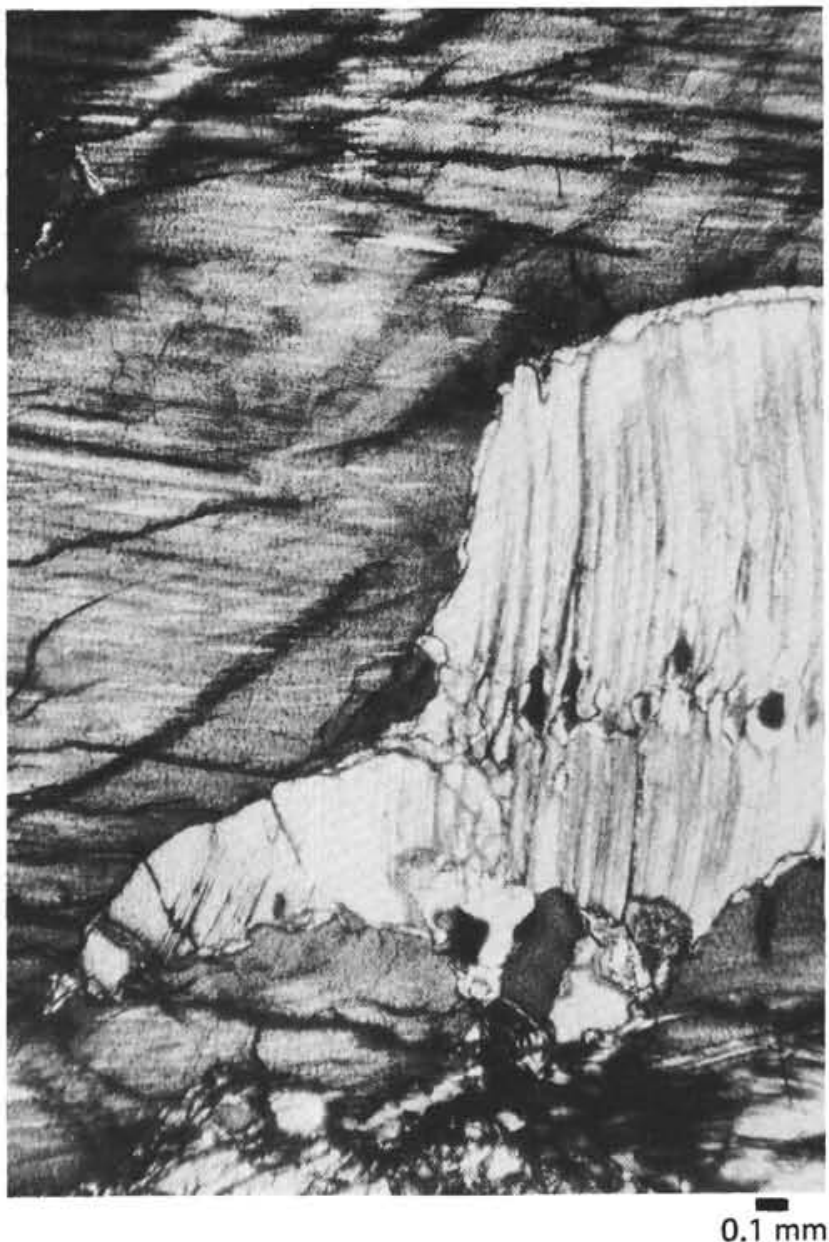

Figure 4. Photomicrograph of a clinopyroxene porphyroclast (white) associated with an enstatite porphyroclast (gray). Lherzolite, piece 17f; crossed nicols. 


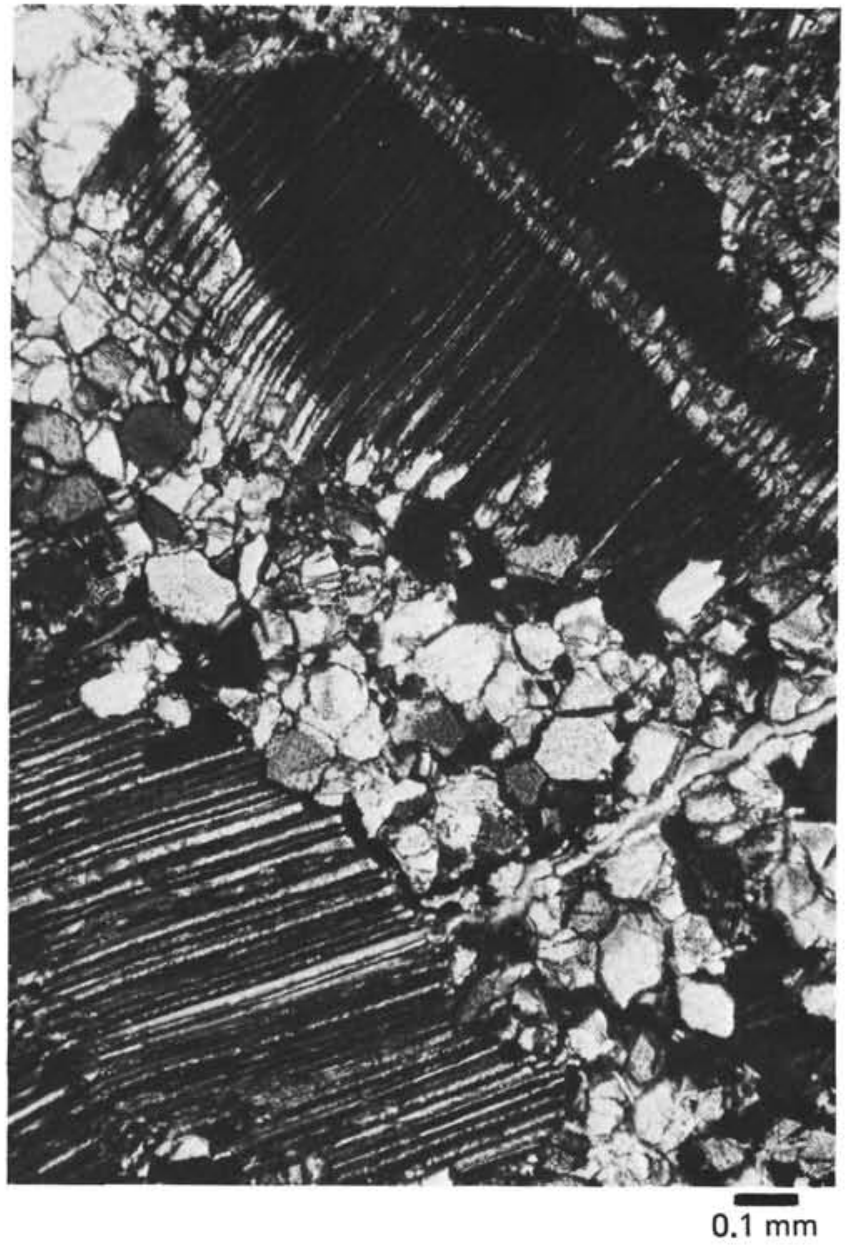

Figure 5. Photomicrograph of a clinopyroxene porphyroclast with sub-boundary perpendicular to the (100) exsolution lamellae and recrystallized neoblasts forming $a$ string parallel to the sub-boundary. Lherzolite, piece $17 f$; crossed nicols.

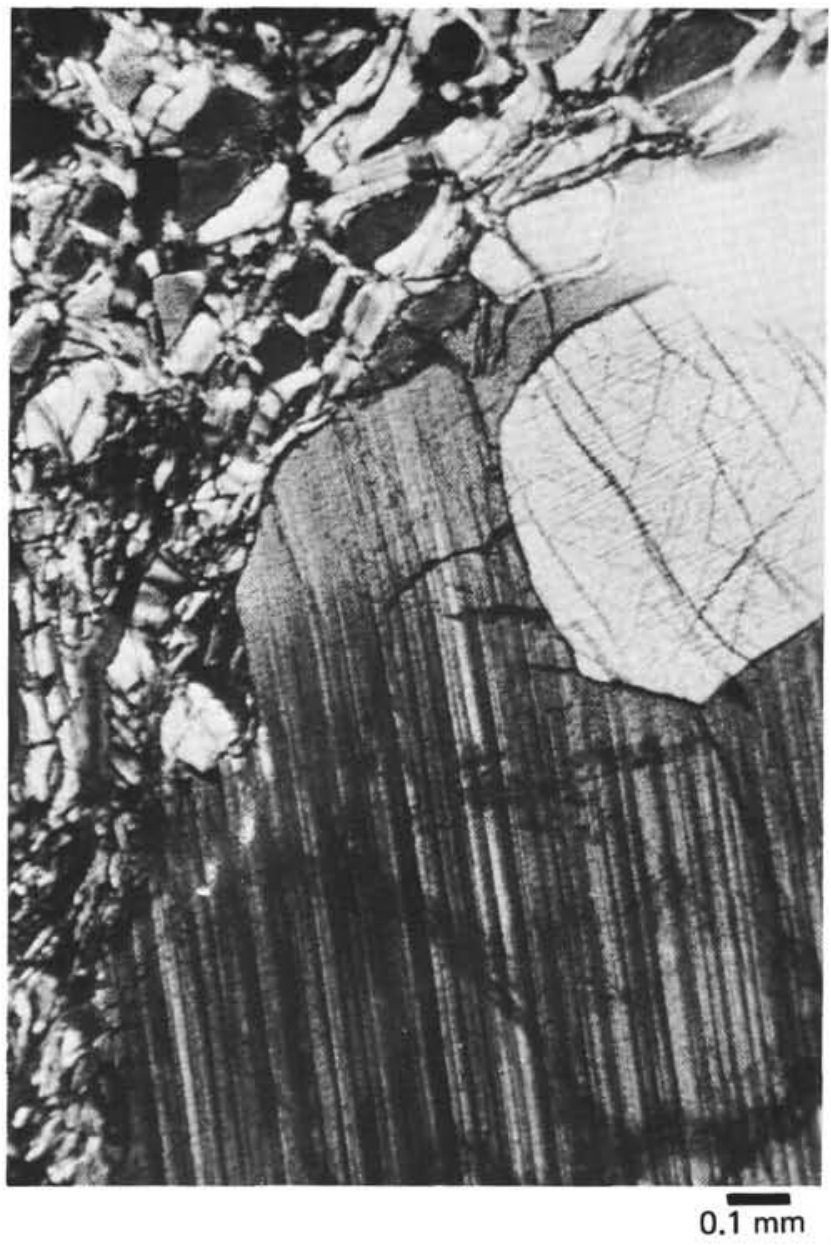

Figure 6. Photomicrograph of an idiomorphic clinopyroxene crystal associated with porphyroclastic enstatite. Lherzolite, piece 17f; crossed nicols. 


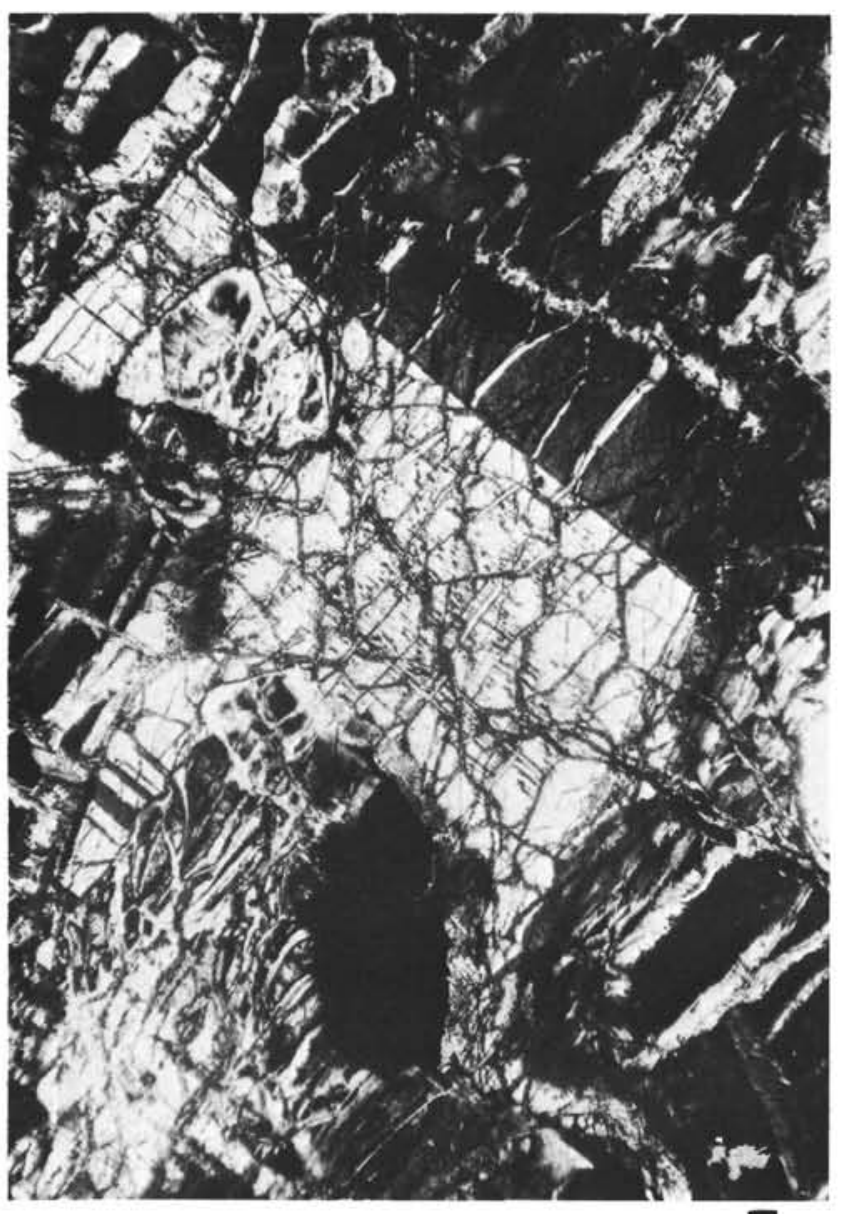

$0.1 \mathrm{~mm}$

Figure 7. Photomicrograph of a twinned clinopyroxene crystal in harzburgite, piece $2 \mathrm{~g}$; crossed nicols.

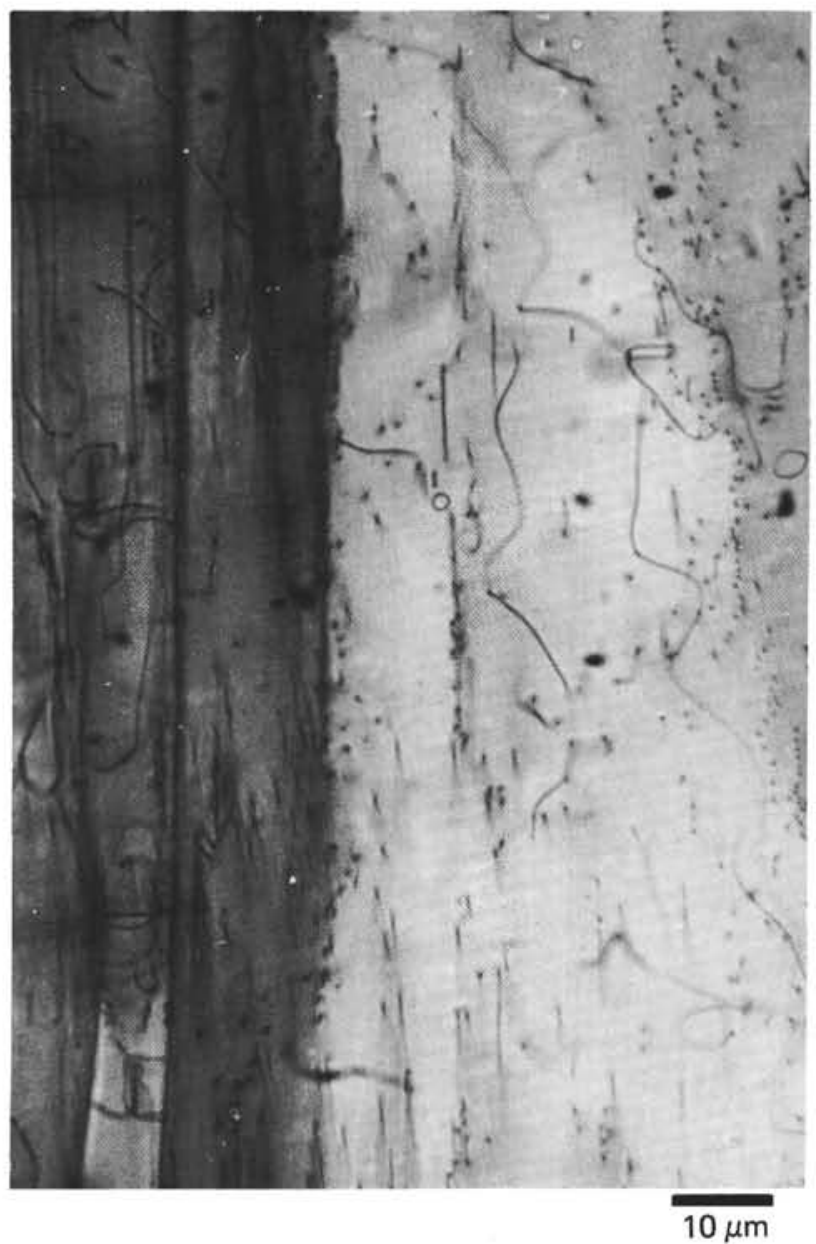

Figure 8. Photomicrograph of a decorated olivine crystal showing perfect (100) walls (vertical, to the left), imperfect (100) walls (vertical, to the right), and looped free dislocations. Harzburgite, piece 2g; parallel nicols. (Picture from Y. Gueguen.) 
F. BOUDIER
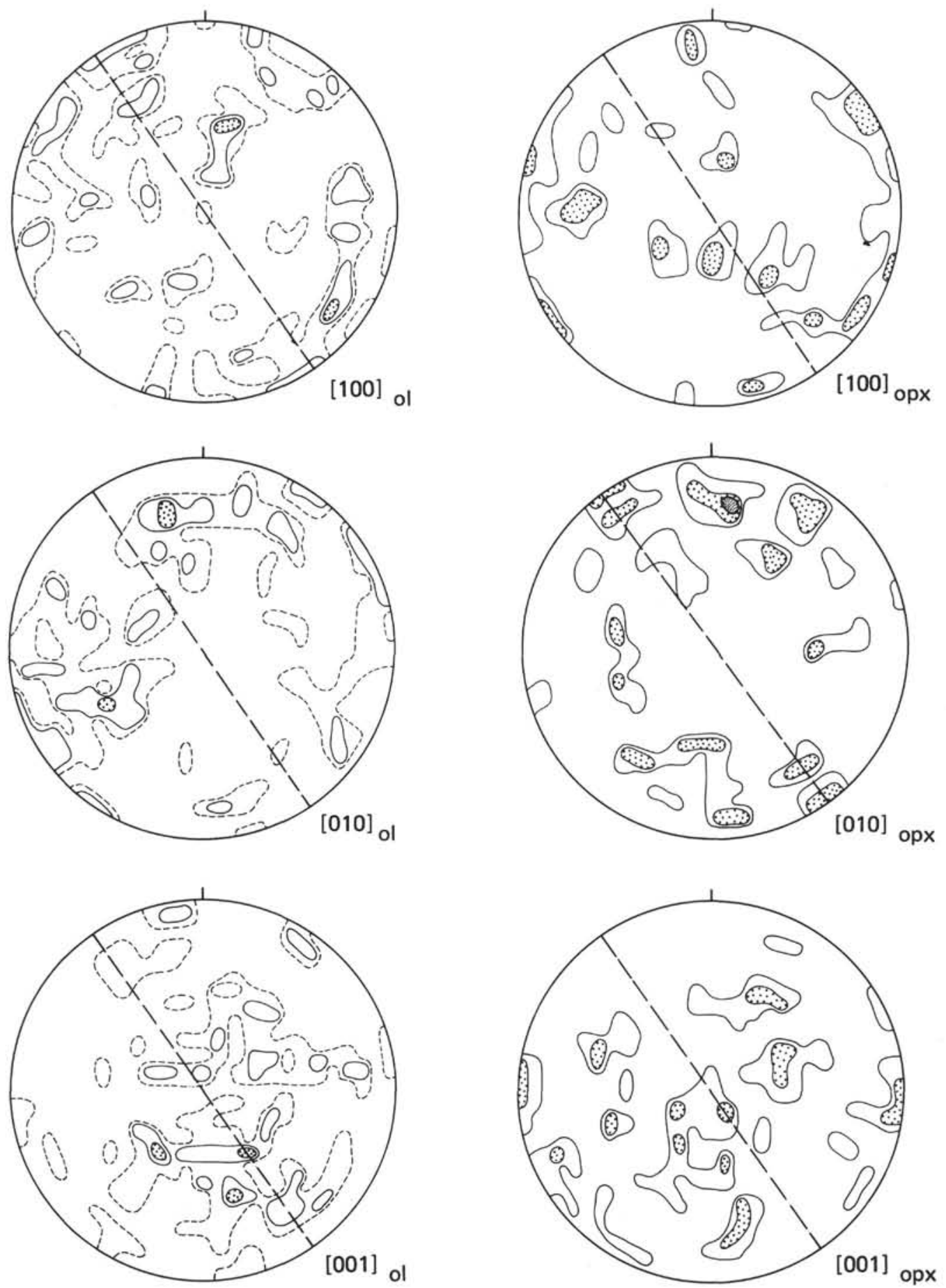

Figure 9. Diagrams of mineral preferred orientation for olivine (ol) 100 measurements, and orthopyroxene (opx) 55 measurements in harzburgite, piece $2 g$. Lower hemisphere projection, contours: $1,2,4,8 \%$ per $0.45 \%$ area. Dashed line: foliation plane assumed from orthopyroxene crystals elongation. 